\title{
Modern Monetary Theory and the Public Purpose
}

\author{
Dirk H. Ehnts* \\ Maurice Höfgen**
}

\begin{abstract}
This paper investigates how the concept of public purpose is used in Modern Monetary Theory (MMT). As a common denominator among political scientists, the idea of public purpose is that economic actions should aim at benefiting the majority of the society. However, the concept is to be considered as an ideal of a vague nature, which is highly dependent on societal context and, hence, subject to change over time. MMT stresses that government spending plans should be designed to pursue a certain socio-economic mandate and not to meet any particular financial outcome. The concept of public purpose is heavily used in this theoretical body of thought and often referred to in the context of policy proposals as the ideas of universal job guarantee and banking reform proposals show. MMT scholars use the concept as a pragmatic benchmark against which policies can be assessed. With regards to the definition of public purpose, MMT scholars agree that it is dependent on the socio-cultural context. Nevertheless, MMT scholars view universal access to material means of survival as universally applicable and in that sense as the lowest possible common denominator.
\end{abstract}

Keywords: Modern Monetary Theory, Public Purpose, Economy for the Common Good, Fiscal Policy, Monetary Policy

*Technical University Chemnitz; dehnts@googlemail.com

** Samuel Pufendorf-Gesellschaft für politische Ökonomie e.V./ Pluralism in Economics Maastricht) maurice.hoefgen@outlook.de

\section{Introduction}

While the concept of "public purpose" is widely discussed in political science and philosophy, it is hardly discussed at all in the orthodox school of the economics discipline. Arguably, the neoclassical school of thought, which still dominates the economic discipline, has barely any space for incorporating the concept of public purpose. It builds on a highly individualistic, utilitymaximizing image of society and pictures the economy as a natural entity that is beyond societal control and functions best if left to itself, i.e. left to market forces. Consequently, the role of the government is limited to that of a moral arbiter, whose aim, ultimately, is restricted to the creation 
of a level playing field among economic actors. Any attempt to actively steer the economy by fiscal policy simply distorts the economy. The idea that government spending crowds out private investment plans, thereby harming the private sector, is but one example. While Modern Monetary Theory (MMT), as part of economic heterodoxy, challenges neoclassical assumptions and offers an alternative approach to economics, this paper investigates how the concept of public purpose is incorporated into MMT.

The paper is organized as follows. Section 2 discusses a definition of public purpose in order to establish a benchmark against which incorporation within the MMT framework can be evaluated. For that purpose, definitions as well as conceptual critiques from academic disciplines other than economics are considered as well. Section 3 provides a brief introduction to the theoretical body of MMT and explains what distinguishes MMT from other approaches to macroeconomics. Section 4 investigates in how far MMT incorporates the concept of public purpose and compares its definitions with those from other academic areas. Section 5 concludes.

\section{How to define "public purpose"?}

The concept of the public purpose is intensively and controversially debated in the areas of political science as well as in philosophy and law. In comparison, there is only a minor discourse on the subject within the discipline of economics, mainly located in heterodox schools of thought. While a full representation of all controversies is beyond the scope of this paper, this section aims at establishing a working definition against which the case for MMT can be assessed.

Political scientist Bozeman (2007) follows Fesler's (1990) argument that the concept of public purpose (or public interest, as he terms it) is an ideal rather than a scientific, instrumental, measurable construct. Nevertheless, both agree that this ideal - though not concretely measurable - has pragmatic importance, as it can justify or motivate specific policies and establishes at least a vague benchmark against which policies can be assessed. In awareness of its ambiguity, Bozeman establishes the following working definition: "In a particular context, the public interest refers to the outcomes best serving the long-run survival and wellbeing of a social collective construed as a 'public'." (Bozeman, 2007, p. 12). Not only does he acknowledge the ambiguity of this undefined ideal, but also the normative character, which is embedded in the concept of public purpose. On top, as he stresses, the focus of his definition lies on the outcomes and not on the intentions of a certain policy (Bozeman, 2007). One of the key questions that arises is: does the ideal of the public purpose require that all members of society benefit from a policy or is a policy that is beneficial for the majority sufficient to satisfy the ideal? Since the public purpose is usually discussed against the background of politics and democracy, it seems to be clear that there might be winners and losers. In the US, provisioning health care through government agencies would take away existing private sector profits, for instance. Nevertheless, the public purpose would be served. This view clashes with the timeless idea of Pareto efficiency. Pareto efficiency is reached when it is impossible to reallocate resources in society without making at least one person worse off. This, of course, is a highly restrictive assumption and policies that fullfil the criteria of Pareto efficiency are scarce. The concept lends itself to strengthening the status quo in society and has been attacked on those grounds (Flomenhoft 2017). 
Public purpose and democratic society

Referring to the normative and ideational character of the concept of public purpose, Bozeman (2007) implicates that a full representation of all members of society is desirable in terms of sketching the public interest for a given time and context. However, he perfectly recognizes that there is no universal answer to what constitutes the public purpose in pluralistic and diverse societies. Hence, a full representation of all members of society might not be feasible. Relatedly, Cox (1973) and Downs (1962) argue that a reflection of the majority interest in democratic constitutions is a satisfactory approach. From this, it can be inferred that the concept of democracy is inherently related to the public purpose. It is acknowledged, that while it is nearly impossible to formulate a universal but concrete answer to what the public interest is, democratic practices are able to express the public interest (public purpose) for a majority for a given time and context. Consequently, society's answer to what the public purpose is can change over time and is dependent on the socio-economic context. Most liberal democratic societies have some sort of constitutional protections of minorities in place that make it politically more difficult to change the status quo.

In the field of law, the concept of public purpose has roots in the constitutional history of America and is referred to under the term "public policy doctrine". Essentially, public policy doctrine holds that public policies and fiscal spending as well as taxation decisions must aim to benefit the populace as a whole. This includes the principle that governmental action directed at private actors serves the public end. Accordingly, the construed public interest overrides the interest of a particular citizen favoring the bestowing of benefits upon the collective (Martinez-Fraga \& Reetz, 2015; Scheiber, 1986). Ultimately though, even in the context of law and legal definition, the criteria for public purpose are neither objectively defined nor measurable, which is mainly related to the normativity that is inherent to the concept of public purpose. Consequently, the concept of public purpose requires discursive reasoning, which links the whole concept to democracy. In that light, the normative character of the concept is linked to the idea of a country's sovereignty. In the context of international law, and in times of sharply increasing numbers of trade and investment agreements, concerns have been raised that the concept is elusive. The very fact that the concrete interpretation of public purpose is dependent on time as well as on context and, this being a source of a country's sovereignty, makes it hard to find an universally applicable legal definition (Martinez-Fraga \& Reetz, 2015).

\section{Public and private sector}

Moreover, the idea of public purpose is in opposition to the existence of aggregated private interests, which is discussed controversially. Anthropologist Kennedy (1959) justifies public purpose by arguing that individuals are, as social beings, members of multiple groups and those memberships create joint public interests, which possibly, though not necessarily, differ from mere individual interests. She argues further that it is reasonable to expect that humans - as part of social organizations - are used to accept commitments both in the form of privileges and obligations. This view, obviously, is in complete contrast to the neoclassical body of economics, which assumes humans to be rational, egoistic, utility-maximizers (Mankiw, 2014; Samuelson, 1938). 
As neoclassical economists assume that the optimal societal outcome is reached when all members of society individually maximize their utility, it is not surprising that neoclassical economists don't work with the concept of public purpose.

Consequently, Mazzucato (2018) raises complaints about the fact that the concept of public purpose is rarely touched in neoclassical economics. In this light, she discusses the term "public value" and argues that neoclassical economics undermines the possibility that governments can actively and productively contribute to society, with actions that exceed the mere role of fixing market failures. As she frames it, the concept of public purpose is linked to the prosperity of society. Mazzucato moves from the theoretical to the practical sphere. She insists, for example, that policies that direct the economy towards less inequality and more broadly shared prosperity serve the public value. Likewise, she argues that the financial sector in its current state is best considered as a drain of value and, hence, does not optimally serve society. Clearly, the ambiguity and normativity acknowledged by Bozeman (2007) and Fesler (1990) is also perfectly reflected in Mazzucato's statements. While one can grasp her intentions, ultimately, the concrete definition of public purpose remains unclear. Chick (2018) discusses public purpose in the context of industrial policy. She points out that today the phrase is out of use and, perhaps, almost unmentionable. In a white paper by the UK Conservatives, the government's purpose would be "industrial success". This connects to the idea that the people serve the economy and not the other way around, as Mazzucato and others have it. Arguing for an "entrepreneurial state" or industrial policy, both economists evoke the concept of public purpose (or public value). It is clear for both authors that it is the government's task to pursue the public purpose.

Interestingly, Felber (2015) suggests that private (and public) firms should pursue the public purpose. He stresses the fact that many democratic constitutions refer to terms that are quite similar to the public purpose or, as he frames it, the common good. Felber characterizes the common good (or public purpose) by five values: human dignity, solidarity, justice, ecological sustainability and democracy. Notably, and in consensus with both the perspectives held in political science and law, he clearly points out that democracy is an inherent part of both the common good itself as well as the interpretation of the common good. Additionally, in line with political scientists, he concludes that neither profits nor GDP are adequate measures for assessing whether an individual company or even an economy as a whole contribute to the public purpose. Consequently, he suggests an alternative approach based on a mix of monetary and non-monetary (qualitative) indicators for measuring how well an economy serves the common good. Concretely, for corporations, he suggests establishing a common good balance sheet that assesses via several sub criteria in how far corporations contribute to the common good. Referring to the legal definition, which stresses the fact that governmental action directed at private actors must follow a public end, he further requires governmental actions to contribute to the five values that mainly define the common good (Felber, 2015).

\section{A brief Introduction to MMT}

Before the incorporation of the concept of public purpose in MMT is assessed, the following section provides a brief introduction to the theoretical body of MMT. MMT, being a branch of the 
heterodox school of thought, puts the current monetary arrangements at the very center of its analysis using a balance sheet approach to macroeconomic accounting (Ehnts, 2019). That is what most clearly distinguishes MMT from other schools of macroeconomics. MMT provides a different angle from which economic issues can be analyzed and, even more importantly, from which policy options that were not previously considered viable can be derived - most prominently, the Green New Deal with the Job Guarantee program.

From a MMT perspective, the concept of monetary sovereignty and its implications for the size of the policy space available to a government is vital. Monetary sovereignty is understood as a spectrum. The higher the degree of sovereignty, the greater the available policy space, hence, the greater the government's capacity to achieve the desired socio-economic outcome. Essentially, the degree of monetary sovereignty depends on four determinants. The full degree of sovereignty is achieved if, firstly, the government of a nation issues its own fiat currency, secondly, it is able to enforce its tax liabilities denominated in its own currency, thirdly, it does not issue any debt instruments not denominated in its own currency and, lastly, it does not promise to exchange its own currency into anything else at a fixed rate (Bell, 2001; Kelton, 2011; Mitchell, Wray, \& Watts, 2019). While the first condition is fulfilled for most nations, the Eurozone and the CFA Franc zone being the biggest exceptions, some countries peg their currency to a foreign currency or issue foreign-denominated debt, thereby inflicting a technical burden on themselves (Ehnts \& Höfgen, 2019; Mitchell et al., 2019; Mosler, 1998; Wray \& Sardoni, 2007). Such governments, however, can rearrange their institutional arrangements in order to gain the monetary sovereignty required to facilitate any political priority. In reality, huge political costs might be associated with giving up fixed exchange rates and foreign currency-denominated debts. Most developing countries, however, should be able to use their own sovereign currency without technical constraints. Political constraints are different alltogether and independent from the currency question.

MMT acknowledges that a fiat currency is a monopoly of the federal government. The government is the only supplier of that which it demands in payment of taxes. Hence, the government has to spend its currency into existence first, before non-government actors can use it to pay taxes or purchase bonds. It follows further - as a point of logic - that neither taxes nor bond sales finance government spending. It is not the government that needs to collect taxes for its ability to make expenses, but rather the taxpayer that needs to obtain currency in order to be able to pay tax liabilities and/or purchase government bonds. For the currency-issuing government, the primary use of levying tax liabilities on its citizens is not to fund government spending, but to create demand for the currency. As secondary means, taxes serve as a financial drain for the private sector thereby lowering inflationary pressure and freeing up real resources to be commanded by the government to pursue its socio-economic agenda. Additionally, taxes are a means to address inequality or (dis)incentivize certain behaviors. (Bell, 2000; Ehnts, 2016; Mitchell et al., 2019; Mosler, 2012b; Wray, 2014).

As Wray $(2015$, p. 2) puts it: “[...] all of this was obvious 200 years ago when kings literally stamped coins in order to spend and then received their own coins in tax payment." After all, modern money is nothing but a tax credit. In today's world, in which the central bank executes and receives payments from/for the treasury, the complexity of the operational processes has increased, 
however, the underlying logic of how the government spends remains the same. Instead of printing or stamping coins, the government spends (taxes) by instructing its central bank to credit (debit) the reserve account of the recipient's bank, which in turn credits (debits) its customers bank account accordingly. While the operational and institutional procedures in place for the horizontal relationship between the treasury and its central bank - which are beyond the scope of this paper - differ across countries, those are largely irrelevant for the vertical relationship between the consolidated government (government plus its central bank) and the private sector. Any voluntary, self-imposed procedural regulations that constrain the government in its ability to spend are to be considered as economically unnecessary in the context of currency-issuing governments and can only be grounded in political reasons (Ehnts, 2016; Fullwiler, 2008; Mitchell et al., 2019).

As currency issuer, the federal government operates under a completely different logic than currency users such as local governments, corporations and households do. Currency users have to fund their spending by either income, asset sales or borrowing (limited by their creditworthiness). As the monopoly issuer of the currency, the government can make all payments denominated in its own currency as they fall due and has no solvency risk on debt denominated in the currency it issues. Hence, it is able to purchase everything that is for sale in its own currency - including all idle labor offered to it. Essentially, the currency issuing government faces no financial constraints. The constraints a monetarily sovereign government does face are the availability and quality of its real resources as well as the risk of inducing inflation if total spending partly exceeds the productive capacity of the economy. There are other constraints like capital flight and indebtedness in foreign currency or jumps in the exchange rate that are somewhat independent from the choice of currency. Nevertheless, currency issuers can still tie their own hands as the concept of the spectrum of monetary sovereignty demonstrates. For example, this occurs when the government promises to exchange its currency into a foreign currency or a precious metal at a fixed rate. While such a government cannot run out of its own money, it surely can run out of foreign reserves or precious metal forcing it into default on its promise.

The bottom line is that financial affordability is not a valid issue for a monetarily sovereign government (not) pursuing its socio-economic mandate if the real resources are available. Moreover, such a government never needs to pursue any specific fiscal balance but rather should adjust the fiscal balance to whatever magnitude is required to achieve its socio-economic mandate (Ehnts, 2016; Mitchell et al., 2019).

\section{Public Purpose: An MMT-Perspective}

The term "public purpose" is used quite often by the core scholars of MMT. As outlined, MMT stresses that government spending plans should be designed to pursue a certain socio-economic mandate and not to meet any particular financial outcome such as a balanced government budget. As Mosler (2010, p. 29) puts it: "The right amount of government spending has nothing to do with tax revenues or the ability to borrow, as both of those are only tools for implementing policy on behalf of public purpose, and not reasons for spending or not spending, and not sources of revenue needed for actual government spending.". Likewise, Mitchell and Fazi (2017, p. 191) mention that: "Any assessment of the fiscal position of a nation must be taken in the light of the usefulness of 
the government's spending programme in achieving its national socio-economic goals.". While MMT builds partly on the insights of Abba Lerner, Mitchell and Fazi (2017, p. 191) continue: "This is what Lerner called the 'functional finance' approach. Rather than adopting some desired fiscal outcome (such as achieving fiscal surpluses at all costs), governments ought to spend and tax with a view to achieving 'functionally' defined outcomes, such as full employment.". Moreover, Mitchell and Fazi (2017) state that the public purpose of government policy should be the pursuit of full employment and an increased level of well-being of its citizens. Likewise, Wray and Semenova (2015) refer to the public purpose as improvement of the living standards of the majority of the population on this planet.

Interestingly, Ruml (1946), who also acknowledged that tax revenues are obsolete for currencyissuing governments' expenditures, already refers to the public purpose in his work on how tax policies can increase prosperity. Concretely, he proposes that tax policies should serve the aims of stabilizing the purchasing power of the currency, address the distribution of wealth and income, (dis)incentivize behaviors and industries and direct the costs of certain national benefits towards those actors who utilize the benefits. As touched upon in section 3, this position is also perfectly reflected in the theoretical body of MMT. He explicitly mentions that tax policies as much as other policies are a means to an end, the end being to serve the public purpose. The position of the MMT scholars Mitchell, Wray and Watts (2019) is very close to that of Ruml and goes even a bit further in picturing the economy to serve not only the populace but also respecting environmental boundaries.

Wray (2015, p.196) explicitly picks up on the question of how public purpose can be defined: "What is the public purpose? It is not easy to define or to identify. One of the basic functions of any social organization is to provide the necessary food, clothing, shelter, education, health care, legal framework, and socialization for the survival of the society. While the subject of this Primer is macroeconomics, there is no sharp distinction between the sphere of economics and the concerns of other social sciences that study social processes. We usually think of the economy as the main part of social organization that is responsible for provision of the material means of survival: food, clothing, shelter, and so on. However, the economy is always embedded in the social organization as a whole, affecting and affected by culture, politics, and social institutions. Even if we can agree that any successful economic organization should be able to produce adequate food for its population, that still leaves open many questions: What kind of food? How should it be produced? How should it be distributed? What does adequate mean?". While this is very much in line with the discussions going on in political science and law as summarized in section $2-\mathrm{i}$. e. the term public purpose being an abstract ideal, which is dependent on the socio-cultural context and inherent to the concept of democracy. - it is worth mentioning that Wray (2015) establishes the access to material means of survival as indispensable for a universal definition of the concept. In this light, access to material means of survival can be understood as the least common denominator for any definition of the concept regardless of the context. Moreover, Wray (2015) implicitly stresses that the role of collective decision-making and discursive reasoning is crucial in modern democracies. On that note, scholars belonging to the school of Modern Monetary Theory stress the importance of monetary sovereignty for a government's ability to implement all democratically determined policies. A reduced degree of monetary sovereignty, e. g. due to a currency peg or the 
membership in a currency union such as the EMU, harms a government's ability to serve the public purpose.

While Wray (2015) mentions that it is the role of the government itself to serve the public purpose as well as to align private interests with the public purpose, Mosler (2010, p. 99) is more concrete and defines the functions of the government as follows: "Functions of government are those that best serve the community by being done collectively. These include: The military, the legal system, international relations, police protection, public health (and disease control), public funding for education, strategic stockpiles, maintaining the payments system, and the prevention of "races to the bottom" between the states, including environmental standards, enforcement standards, regulatory standards and judicial standards." On top of that, MMT scholars agree that it is the responsibility of the government to prevent involuntary unemployment for both economic and social reasons. Hence, MMT scholars argue in favor of implementing a universal job guarantee program (JG). The job guarantee program (or ELR - Employer of Last Resort) "involves the government making an unconditional job offer to anyone who is willing to work at a socially acceptable minimum wage and who cannot find work elsewhere. It is based on the assumption that if the private sector is unable to create sufficient job opportunities then the public sector has to stand ready to provide the necessary employment. This creates a buffer stock of paid jobs that expands (declines) when private sector activity declines (expands)." (Mitchell \& Fazi, 2017, pp. 230-231). Next to its economic benefits, the JG scheme effectively attacks the societal costs of unemployment, such as: poverty, social isolation, crime, regional deterioration, health issues, family breakdowns, school dropouts, loss of human capital and social, political and economic instability. Simultaneously, the JG program fosters the societal benefits of full employment: poverty alleviation, community building, social networking, and intergenerational stability amongst others. Next to that, the JG increases output in terms of goods and services, offers on-thejob training as well as skill development and addresses inequality since it hires off the bottom of the income distribution by offering a fixed wage and benefits package to anyone willing and able to work (Kaboub, 2007; Tcherneva \& Wray, 2005; Wray, 2015). Following Mitchell and Muysken (2008), who are referring to the declaration of human rights, universal access to a job with a living wage, which accords every citizen access to the material means of survival, is a basic human right. The JG especially lends itself to support grassroots organizations and local level development as well as a Green Jobs Corps (Forstater 2014). When government pays for these jobs, then democracy plays a large role in ensuring accountability. The JG can also be connected to Dr. Martin Luther King Jr.'s "Jobs for All”. Forstater $(2002,45)$ reminds us that the "March on Washington" was officially named "March on Washington for Jobs and Freedom". He believes that "[p] erhaps no single policy could have as great a social and economic impact on the African American community - and the entire country - as federally funded job assurance for every person ready and willing to work (ibid.).

Arguing for a JG as a policy instrument, MMT ensures that the lowest possible common denominator for any public purpose definition - access to material means of survival - is fulfilled. Additionally, the concrete definition of the public purpose is also dependent on personal values. Wray and Semenova (2015, p. 253) mention justice and equality as guiding values: "MMT unveils the power of the monetary system to serve the public interest by restoring healthy and functional communities and building a more equitable and just future via government's commitment to full 
employment. There are no financial constraints that prevent the government from achieving these goals."

Clearly, the MMT scholars seem to be in agreement with Bozeman (2007) and Fesler (1990) that the concept of public purpose has pragmatic importance as it is can justify or motivate specific policies and establishes at least a vague benchmark against which policies can be assessed. This becomes evident in the MMT-based policy proposals, especially when it comes to field of banking and finance. As Mosler (2012a, p. 53) puts it: "Government begins with an assumption that it exists for the public purpose, and I use that as a guiding assumption of my proposals. [...] the public purpose of banks is to provide a payments system and to fund loans based on credit analysis [...] ". With regards to banking reform, Mitchell and Fazi (2017, p. 258) state the following: "Steering the activities of banks towards the advancement of the common good would go a long way towards eliminating the dysfunctional, antisocial nature of private banking and ensuring that these 'public' institutions serve the public purpose." Likewise, Wray and Mazzucato (2015, p. 55) refer to the concept of the public purpose in seven out of eight reform proposals for the commercial banking system.

All in all, it becomes evident that the concept of the public purpose is being used by MMT scholars as a pragmatic benchmark against which policies can be assessed. In that sense, MMT scholars are in agreement with political scientists Bozeman (2007) and Fesler (1990). However, while the ideal and vague nature of the concept seems to be accepted, MMT scholars have established a least common denominator - universal access to material means of survival. On top of that, MMT scholars stress the importance of democratic processes by which a common understanding of the public purpose is to be established. The concrete definition is dependent on the socio-politicocultural-economic context.

\section{Conclusion}

This paper has investigated in how far MMT as part of the economics heterodoxy incorporates the concept of the public purpose, which is mostly neglected by the neoclassical body of thought. The term is discussed controversially among political scientists as well as in the field of law. As a common denominator among those scientists, the idea of the public purpose is that economic actions should aim at benefiting the majority of society. However, public purpose is to be considered as an ideal of a vague nature, which is inherently linked to democracy and the concrete definition of which is highly dependent on the societal context. As such, interpretations of the public purpose might change over time.

MMT, which puts the analysis of the monetary arrangements at its very center, stresses that government spending plans for monetarily sovereign governments are to be designed to pursue a certain socio-economic mandate (or public purpose) and not to meet any certain financial outcome such as a balanced government budget. The concept of public purpose is heavily used in the theoretical body of thought and often referred to in the context of policy proposals as both the idea of the universal job guarantee, and the banking reform proposals show. While - in line with 
political scientists - the ideal and vague nature of the concept seems to be accepted, MMT scholars use it as a pragmatic benchmark against which policies can be assessed. With regards to the definition of the public purpose, MMT scholars agree that it is dependent on the socio-cultural context and, hence, subject to change over time. Nevertheless, MMT scholars view universal access to material means of survival as universally applicable and - in that sense - as the lowest possible common denominator.

\section{References}

Bell, S. (2000). Do taxes and bonds finance government spending? Journal of economic issues, 34(3), 603-620.

Bell, S. (2001). The role of the state and the hierarchy of money. Cambridge Journal of Economics, 25(2), 149-163.

Bozeman, B. (2007). Public values and public interest: Counterbalancing economic individualism: Georgetown University Press.

Cox, J. R. (1973). The appeal to the public interest. British Journal of Political Science, 3(2), 229241.

Downs, A. (1962). The public interest: Its meaning in a democracy. Social research, 1-36.

Ehnts, D. H. (2016). Modern monetary theory and European macroeconomics: Routledge.

Ehnts, D. H. (2019). The balance sheet approach to macroeconomics. Principles and Pluralist Approaches in Teaching Economics: Towards a Transformative Science, 41, 243.

Ehnts, D. H., \& Höfgen, M. (2019). Modern monetary theory: a European perspective. real-world economics review, 75 .

Felber, C. (2015). Change Everything: Creating an Economy for the Common Good: Zed Books.

Fesler, J. (1990). The state and its study: The whole and the parts. Public administration: The state of the discipline, 84-97.

Fullwiler, S. (2008). Modern Central Bank operations: the general principles. Advances in Endogenous Money Analysis, 50-87. 
Kelton, S. (2011). Limitations of the government budget constraint: Users vs. issuers of the currency. Panoeconomicus, 58(1), 57-66.

Kennedy, G. (1959). The process of evaluation in a democratic community. The Journal of Philosophy, 56(6), 253-263.

Mankiw, N. G. (2014). Principles of economics: Cengage Learning.

Martinez-Fraga, P. J., \& Reetz, C. R. (2015). Public Purpose in International Law: Cambridge University Press.

Mazzucato, M. (2018). The value of everything: Making and taking in the global economy: Hachette UK.

Mazzucato, M., \& Wray, L. (2015). "Financing the Capital Development of the Economy: A Keynes-Schumpeter-Minsky Synthesis". Levy Economics Institute of Bard College, Working paper series№ 837.

Mitchell, W., \& Fazi, T. (2017). Reclaiming the state. University of Chicago Press Economics Books.

Mitchell, W., \& Muysken, J. (2008). Full employment abandoned: shifting sands and policy failures: Edward Elgar Publishing.

Mitchell, W., Wray, L. R., \& Watts, M. (2019). Macroeconomics: RED GLOBE PRESS.

Mosler, W. (1998). Exchange rate policy and full employment. Paper presented at the The University of Newcastle, Australia. http://moslereconomics.com/2010/10/04/exchange-ratepolicy-and-full-employment/

Mosler, W. (2010). Seven deadly innocent frauds of economic policy: Davin Patton.

Mosler, W. (2012a). Proposals for the banking system, the FDIC, the FED and the Treasury. In Monetary Policy and Central Banking: New Directions in Post-Keynesian Theory (pp. 53-61): Edward Elgar.

Mosler, W. (2012b). Soft Currency Economics II: The Origin of Modern Monetary Theory. In: CreateSpace Independent Publishing Platform. 
Ruml, B. (1946). Tax policies for prosperity. The American Economic Review, 36(2), 265-274.

Samuelson, P. A. (1938). A note on the pure theory of consumer's behaviour. Economica, 5(17), 61-71.

Scheiber, H. N. (1986). Public Purpose Doctrine. Retrieved 15.08.2019, from Encyclopedia of the American Constitution

https://www.encyclopedia.com/politics/encyclopedias-almanacs-transcripts-and-maps/publicpurpose-doctrine

Wray, L. R. (2014). From the state theory of money to modern money theory: An alternative to economic orthodoxy. Levy Economics Institute, Working Papers Series, Working Paper No. 792.

Wray, L. R. (2015). Modern money theory: A primer on macroeconomics for sovereign monetary systems: Springer.

Wray, L. R., \& Sardoni, C. (2007). Fixed and Flexible Exchange Rates and Currency Sovereignty. The Levy Economics Institute's Working Paper Series, Working Paper No. 489.

Wray, L. R., \& Semenova, A. (2015). The rise of money and class society: the contributions of John F. Henry. In Marx, Veblen, and the Foundations of Heterodox Economics: Essays in Honor of John F. Henry (pp. 252-275): Taylor \& Francis. 